\title{
Jogos na web e o ensino da história da arte
}

Tania Callegaro

Arte-educadora. Doutora em Ciências da Comunicação pela ECA/USP.

Docente no curso de Comunicação Social dos Salesianos - Liceu Coração de Jesus/SP.

E-mail: tcallegaro@cebinet.com.br

\section{INTRODUÇÃO}

[...] num ambiente como a internet, em que a "visibilidade" tornou-se tanto um problema como uma solução, somos levados a acreditar que direcionar a atenção torna-se cada vez mais uma grande responsabilidade $[\ldots]^{1}$.

Para desenvolver o ensino da arte no ambiente da internet por meio de jogos, precisamos definir algumas questões. Qual é a visão que temos da internet? É um espaço de comunicação alternativa ou apenas mais um recurso tecnológico de comunicação como qualquer outro? É suporte de uma nova arte e de uma nova linguagem? É um campo de experiências aleatórias que facilmente desgoverna e desorienta, ou constitui um labirinto de possibilidades?, questiona a web artista Giannetti ${ }^{2}$.

Considerando que a internet traz uma especificidade no processo de circulação e de produção das informações, perguntamos: como expor um trabalho de arte visual com um caráter didático e interativo? Que ensino de arte se constrói a distância em um espaço atualizável, constituído por sujeitos localizados em regiões com culturas diversas e "subjetividades virtuais"? O que e como ensinar sobre as artes visuais por meio de objetos e espaços virtuais?

$\mathrm{Na}$ tentativa de responder a estas questões, estabelecemos alguns parâmetros elaborados a partir da nossa prática e dos autores citados. Primeiro, para discutir sobre a internet na arte-educação é preciso, "concomitantemente, criar com os elementos que ela permite articular, assim como fazem os web artistas que, ao ocupar o seu espaço, revelam as contradições desse ambiente e a complexidade dos modos de existir do homem contemporâneo"3. Nesse contexto, o professor de arte é premido a ser um explorador, semelhante ao artista, e na direção que Huyssen ${ }^{4}$ entende o artista contemporâneo, como um consumidor transgressor, um bricoleur de significados que escapa das pressões e determinações do mercado; ou conforme Flusser sugere, utilizar a máquina "jogando contra ela mesma. É no espaço dessa experimentação que se tem a possibilidade da crítica e da liberdade"

Um segundo ponto de referência é que a recepção na internet, de acordo com Bongiovanni, é diferente da recepção zapeante, de consumo fácil e imediato ${ }^{6}$

1. BAMBOZZI, Lucas. Retratos interativos e situações invasivas. In: Catálogo do 13 VideoBrasil - Festival Internacional de Arte Eletrônica, São Paulo: SESC, p. 217-222, 2001.

2. GIANNETTI, Claudia. Link-Age: tempo lúdico - gesto crítico - espaço poético. In: Catálogo do 13으 VideoBrasil - Festival Internacional de Arte Eletrônica, São Paulo: SESC, p. 144-147, 2001.

3. Ver VANNUCCHI, Hélia. Rompendo com as expectativas do usuário na web. Cadernos da Pós-Graduação, Campinas/SP, Unicamp/ Instituto de Arte, ano 3, v. 3 , n. 1, p. 111-118, 1999. 
4. HUYSSEN, Andreas. Reconsidering the High/Low Debate in Global Context: Aesthetics and Politics in an Age of Globalization (Reconsiderando os debates no contexto global: estética e política na Era da Globalização). Rio de Janeiro, p. 23-24, ago. 2000. Xerox

5. FLUSSER, Vilém. Filosofia da caixa-preta. São Paulo: Hucitec, 1985. p. 57.

6. BONGIOVANNI, Pierre Um espaço público de experimentação. In: Catálogo do 13 을 VideoBrasil Festival Internacional de Arte Eletrônica, São Paulo: SESC, p. 190, 2001.

7. HUYSSEN, Andreas. Reconsidering the High/ Low Debate..., op. cit., p. 23-24.

8. Ibid., p. 23-24.

9. BUENO, Maria Lúcia. Artes plásticas no século XX: modernidade e globalização. 1. ed. Campinas, SP: Editora da Unicamp, 1999. p. 263.

10. BARBOSA, Ana Mae. $A$ imagem no ensino da arte: anos oitenta e novos tempos. São Paulo: Perspectiva; Porto Alegre: Fundação loschpe, 1991. p. 84-85. que a TV, o rádio e a revista estabelecem com o público. A internet exige uma participação mais atenta, curiosa, paciente e ativa, ou melhor, intencionada. O terceiro é o contexto em que a internet se situa, próximo àquele que Huyssen define como modernidade alternativa. Conforme o autor, essa modernidade se constitui por fluxos e embates horizontais da cultura, incrementados pelas novas mídias e pelo processo crescente de globalização e comunicação ${ }^{7}$. Tais fluxos levam à produção de diferentes formas culturais, novos imaginários urbanos, "novos mix de tradição local com operações globais". Nesse contexto, Bueno (1999), quando discorre também sobre os processos de globalização na arte, destaca a "desintegração de fronteiras" entre a cultura alta e a baixa, ou da elite e dos excluídos, do culto e do popular.

Portanto, consideramos que a internet apresenta uma potencialidade específica para o ensino da arte que está em sua dinâmica conflituosa, passageira, comunicacional e permeável a todos os tipos de intervenções híbridas, lúdicas, interativas e coletivas.

\section{ESPAÇOS ABERTOS PARA CIRCULAR, VENDER E ENSINAR A ARTE}

Os jogos para ensinar arte na internet funcionam como mais uma forma de preparar grandes públicos para o consumo da arte. Tal processo, conforme afirma Barbosa ${ }^{10}$, é recente: ocorre desde o final do século XIX.

Na sociedade atual, a divulgação da arte e de sua história com uma preocupação didática e comercial acontece em diferentes espaços, como nas escolas formais, galerias e oficinas de arte, nos ateliês e museus; na mídia, como jornal, revista, TV, rádio, CD-ROM, livro, vídeo, cinema e internet. Acentua-se a articulação das mídias com as ações educativas desenvolvidas dentro da exposição e fora dela e das escolas formais e informais de arte.

As interpenetrações desses espaços de arte determinam a formação de novos públicos, novos profissionais, de novos sentidos para a arte, que enriquecem a dinâmica e o repertório dos meios de comunicação e informação.

As ações educativas de arte não ficam mais restritas ao local e aos profissionais da escola oficial de arte e de seus ateliês. Há uma relação estreita entre o ato de divulgar a arte - de fazê-la circular em espaços diversificados e para diferentes públicos, nacionais e internacionais -, de vender a arte e os seus subprodutos (camisetas, bottons, livros, CDs, objetos, entre outros) e de apresentá-la aos diferentes públicos por meio de programas educativos.

A ação educativa em arte, componente da arte-educação, é o setor específico e fundamental que prepara o público para aproximar-se conscientemente da arte e ser um consumidor de arte, no sentido de que pode selecionar, entender e transformar de modo significativo a carga de informação que lhe chega.

Nesse contexto, a internet torna-se uma extensão e um espaço a mais que intensifica as ações e os movimentos de consumo e de educação que envolvem o mundo da arte com suas diferentes instituições, grupos sociais e culturais. A escola oficial e o seu professor de arte, por sua vez, são envolvidos e chama- 
dos, podemos dizer até pressionados, a integrar-se nesse movimento cultural e de mercado, no fluxo informacional e globalizado da arte.

Os jogos na internet dirigidos ao ensino da história da arte fazem parte desse fluxo informacional e de consumo da arte, da "babel visual que envolve a todos" ${ }^{11}$. Ao mesmo tempo, mantêm relações distantes com a linguagem do videogame e sua iconografia ${ }^{12}$ e fazem parte da recreação solitária no espaço coletivo da internet.

Contudo, devido à interface tecnológica de comunicação a distância com suas possibilidades dialógicas e de informação, como os bancos de dados, o fórum, o chat, os links e o e-mail, esses jogos ancorados na internet trazem a possibilidade do diálogo entre grupos distantes, de interação e do gesto crítico; que, nos casos a serem analisados, ainda são pouco explorados.

\section{ENSINO DA ARTE NO CONTRAFLUXO DE UM CENÁRIO IMPRECISO E FLUIDO}

O que permite, então, transformar esses jogos imersos no "imenso arquivo de imagens circulantes, com referências que viajam embaralhadas e desconexas"13, em uma atividade de arte educativa? É suficiente que os jogos estejam na internet disponíveis e com uma estrutura voltada para uma ação educativa em arte? Estariam eles colaborando para o processo autofágico ${ }^{14}$ que ocorre na sociedade contemporânea pelo excesso de informação? Flusser, em 1985, apontou para um esgotamento no sentido das imagens que a máquina fotográfica desencadeou em seu processo instântaneo e aparentemente fácil de produção. Onde está o limite entre o esgotamento e o gesto crítico na internet?

O fluxo informacional que chega às pessoas é constituído de excesso de informação veiculada em uma velocidade crescente por meio das novas tecnologias e sua instantaneidade. Ele reitera a ideologia do consumo e do descartável, reafirma a supremacia da ciência, da lógica racional e da melhor eficiência. Porém, ao mesmo tempo em que esse fluxo pode levar para o descontrole e a sobrecarga de informação, ele traz consigo a possibilidade do exercício da liberdade. Segundo Bueno, traz elementos do fluxo que permitem "resgatar de forma sensível, interativa e intuitiva o sentido e a integridade da experiência que está contida e perdida nesse fluxo"15. Desta forma, caminha-se no contrafluxo.

O contrafluxo, define Bueno (2001), é produto de um projeto que pressupõe uma intenção. Nele há o gesto crítico que se opõe ao gesto eficiente - cuja motivação e força motriz são alheias ao sujeito. O "gesto crítico é a expressão de uma decisão que torna manifesta uma existência, que coloca outro sentido às coisas" $"$.

Portanto, entendemos que um programa de ensino da arte visual na internet que trabalha com jogos poderia: 1. direcionar a atenção dos jovens para situações particulares que lhes permitam distinguir, selecionar imagens e exercitar a construção de novos conceitos e valores estéticos; 2. proporcionar uma recepção ativa/interativa, coletiva e lúdica diante da história da arte; 3.
11. BUENO, Maria Lúcia. Fluxo e contrafluxos. In: BOUSSO, Vitoria Daniela (Curadoria). Rede de tensão. São Paulo: Imprensa Oficial do Estado/Paço das Artes, 2001. p. 80-84.

12. Ver MIRANDA, José Luiz. Jogos interativos e cotidiano escolar. In: CITELLI, Adilson (Org.). Aprender e ensinar com textos não-escolares. 3 . ed. São Paulo: Cortez, 2000. p. 169-187. (Coleção Aprender e ensinar com textos, 3).

13. BUENO, Maria Lúcia. Fluxo e contrafluxos..., op. cit., p. 83.

14. BAMBOZZI, Lucas. Retratos interativos..., op. cit., p. 223.

15. BUENO, Maria Lúcia. Fluxo e contrafluxos..., op. cit., p. 83.

16. GIANNETTI, Claudia. Link-Age..., op. cit., p. 145-146. 
transformar uma percepção casual em uma percepção precisa; 4. apresentar diferentes propostas contemporâneas da arte que exploram o jogo, o acaso, o lúdico, a desconstrução, o transitório, a experimentação e a partilha; 5. explorar o diálogo verbal e escrito, o som e a integração da imagem fixa e em movimento; 6. criar uma estrutura aberta e interativa, suficiente para incorporar as interferências e o repertório estético dos alunos; 7. acompanhar o processo educativo nos espaços virtual e real, com os educadores e seus alunos.

\section{JOGOS ON-LINE: CAMINHO PARA ESTUDAR AS POÉTICAS DA EXPERIMENTAÇÃO E DA CONEXÃO}

A interatividade na arte institui o talvez na obra, a incerteza e o movimento das formas e da autoria; colabora com o que Haroldo de Campos (1977) denomina de "deslocação estética da clausura logocêntrica"17.

Segundo Plaza, a poética da experimentação da década de $1990^{18}$ opera por meio de uma participação lúdica, do "faça por si mesmo", em que privilegia primeiro o experimentar, para, depois, se chegar à descoberta, à teoria e à reflexão; observa-se o fenômeno para apreender as suas leis. No processo de criação dessas propostas, a concepção e a realização da obra são concomitantes. Nessa perspectiva, o interesse não está em estudar uma obra acabada, mas no processo do fazer experimental que leva a resultados não esperados.

A internet na década de 1990 permitiu o desenvolvimento acelerado dos sistemas em rede, da comunicação global, do conceito de interatividade como lugar de encontros fundado sobre os processos de comunicação. No campo das artes visuais, a internet concretiza o que já estava latente nos anos anteriores: a subtração da forma e a valorização do evento, do fluxo como processo dinâmico vivo. Nesse sentido, segundo Plaza, não há mais uma relação triangular entre autor-obra e receptor, mas circular, em que os "três não ocupam mais posições definidas e estanques, (porque) trocam constantemente estas posições, cruzam-se, opõem-se e se contaminam"19.

As propostas contemporâneas que buscam a experiência artística por meio arte no horizonte do provável e outros ensaios. 4. ed. São Paulo: Perspectiva, 1977.

18. PLAZA, Julio. Arte e interatividade: autor obra - recepção. Cadernos da Pós-Graduação, Campinas/SP, Unicamp/ Instituto de Arte, ano 4, v. 4, n. 1, p. 23-39, 2000.

19. Ibid., p. 38.

20. PEREIRA, Adriana Camargo. A interface lúdica na multimídia aplicada ao ensino. Cadernos da Pós-Graduação, Campinas/SP, Unicamp/Instituto de Arte, ano 3, v. 3, n. 2, p. 9-16, 1999. do jogo exploram a linguagem multimídia e hipertextual das tecnologias digitais e da internet, e desenvolvem-se sob um modo particular, isto é, a partir das escolhas que o visitante/receptor tem disponível, das variadas respostas que a máquina lhe dará, do feedback e das possibilidades de diálogo que terá com outros visitantes.

O jogo é estrutura e proposta das poéticas da experimentação, que permite, com maior ou menor grau de interatividade, um contato, uma participação que leva a uma mudança contínua no contexto em que se joga e nas formas resultantes. Em um jogo, há desafios a superar, regras a cumprir, caminhos a percorrer, errar, ir-voltar e descobrir. Exigem-se ações e interações. "Dessa forma, o conhecimento é construído por meio do estímulo que a experiência do jogo promove." 20

A arte presente na Web Arte e na Arte digital tem como base a ação e o lúdico. 


\section{EM QUESTÃO: OS JOGOS}

Ao criar na internet obras que exploram sua linguagem multimídia e hipertextual, a interatividade, o jogo e o estar com o outro, é introduzido ao jovem a arte e a linguagem de seu tempo, o que promove uma relação mais ativa com o produto artístico e o surgimento de novos desafios para o professor de arte, na medida que tem de atender esse público familiarizado com jogos eletrônicos de maior complexidade.

Segundo Plaza, o aspecto educacional das linguagens interativas e digitais se concretiza quando passamos do ato de ler - entendido como apropriação interna de sentidos de vários textos - para o processo de escrever, que consiste no encadeamento dessas leituras. Portanto, sugerimos que durante e após o jogo é importante que o jovem possa ver e deixar o seu percurso inscrito no trabalho, como escrituras que são construídas a partir dos programas, das propostas e informações concebidas e concedidas por outros.

Dos 14 jogos analisados ${ }^{21}$, presentes em cinco sites de artistas, associações de arte, de museus e de espaço cultural, encontramos o site do artista Arthur Omar, localizado no Museu Virtual, que apresenta a produção desse artista e seu pensamento por meio de um jogo da memória. Ao final de cada fase do jogo há perguntas que nos levam a pensar sobre a arte. Matteo Moriconi, idealizador dessa atividade, vê no jogo um modo de combinar os significados de uma obra numa dimensão de massa, sem vulgarizá-la. A informação textual não é necessária para se jogar, mas, segundo Moriconi, é importante caso se deseje ter mais prazer no jogo e aprofundar as suas questões ${ }^{22}$.

\begin{tabular}{|c|c|c|c|c|c|c|c|c|c|c|c|c|}
\hline \multicolumn{12}{|c|}{ E Museu Virtual de Ante Brasileira - Alte Contemporânea - Microsoft Internet Explorer } & \multirow{2}{*}{$\frac{-10 x}{\text { 田 }}$} \\
\hline Arquivo & Editar & Exibir & Eavoritos & s $\mathrm{Fer}$ & entas Aiu & & & & & & & \\
\hline$\underset{\text { Voltar }}{\stackrel{4}{ }}$ & $\cdot$ & $\begin{array}{c}\Rightarrow \\
\text { Awancer }\end{array}$ & - & Parar & Alualizat & Página inicial & Pesquisar & Favoritos & Histórico & Correio & Imprimir & $"$ \\
\hline
\end{tabular}

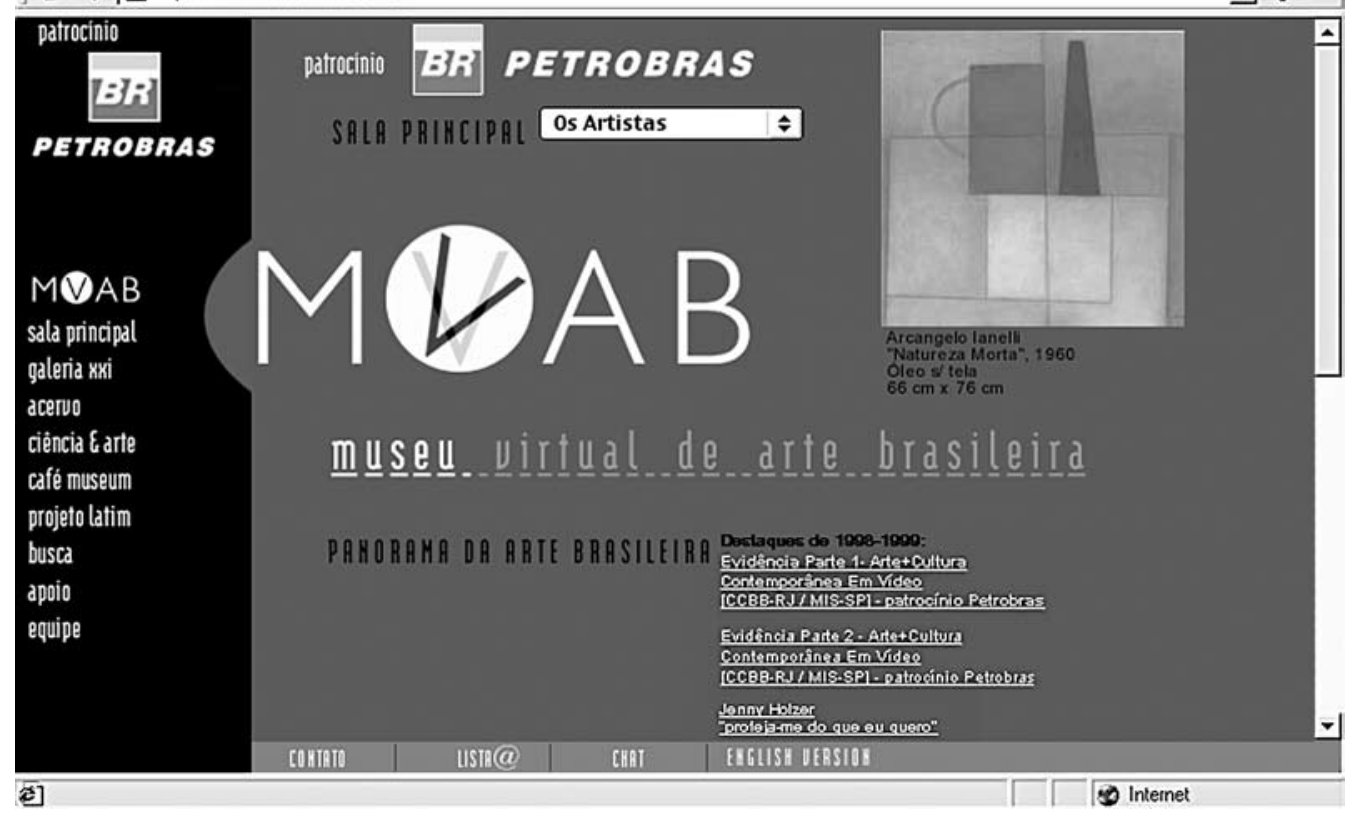

21. 1. Itaú Cultural - Núcleo de Projetos de Ação Educacional. Disponível em: $<$ http://www.itaucultural. org.br>.

2. Museu Virtual de Arte Brasileira. Disponível em: $<$ http://www.museuvirtual. com.br>

3. Eyes on Art Quiz. Disponível em: <www.kn.pacbell. com/wired/art2/quiz/index. html>.

4. Museu Portinari. Disponível em: <www.portinari. org.br>

5. Pintura - Art Detective Educational Web Adventures. Disponível em: <http://www.eduweb. com/pintura>.

22. Disponível em: <http:// www.museuvirtual. com.br/ arthuromar>. 
Em geral, os jogos analisados pedem um controle motor simples com o mouse e uma atenção visual um pouco forçada para os limites da tela do computador. Apresentam um nível de interatividade simples e o caráter dos jogos de exercitação, nos quais o participante arrasta pedaços de um quebra-cabeça ou clica sobre outros pertencentes a um jogo da memória. Os jogos em questão estabelecem uma relação lúdica e prazerosa presentes no ato de ver e entender a arte; criam uma atmosfera propícia para iniciar uma discussão sobre a história da arte visual e oferecem informações básicas sobre o artista e sua obra. Incentivam, portanto, a análise visual e a pesquisa; exercitam a percepção visual, a concentração, os processos de busca e de descobertas. As atividades fazem uma relação entre o texto, as imagens e os sons do jogo. Destacamos a excelente qualidade visual de todos os sites, dos blocos de informação visual e textual que acompanham os jogos e a preocupação de estabelecer uma navegação amigável e animada com os usuários da internet, uma vez que não exigem programas e aplicativos complexos para jogar ou baixar.

Sob a perspectiva da arte-educação e das idéias aqui presentes, entendemos que essas atividades lúdicas podem crescer potencialmente quando integradas a um trabalho de reflexão e de interpretação criativa e coletiva no ambiente da internet, com atividades, por exemplo, que explorem as propostas das poéticas da experimentação e que deixem marcas de presença de cada jogador/receptor no espaço virtual.

A correspondência da linguagem sonora e musical com a da imagem animada e em vídeo é também caminho a explorar nos jogos.

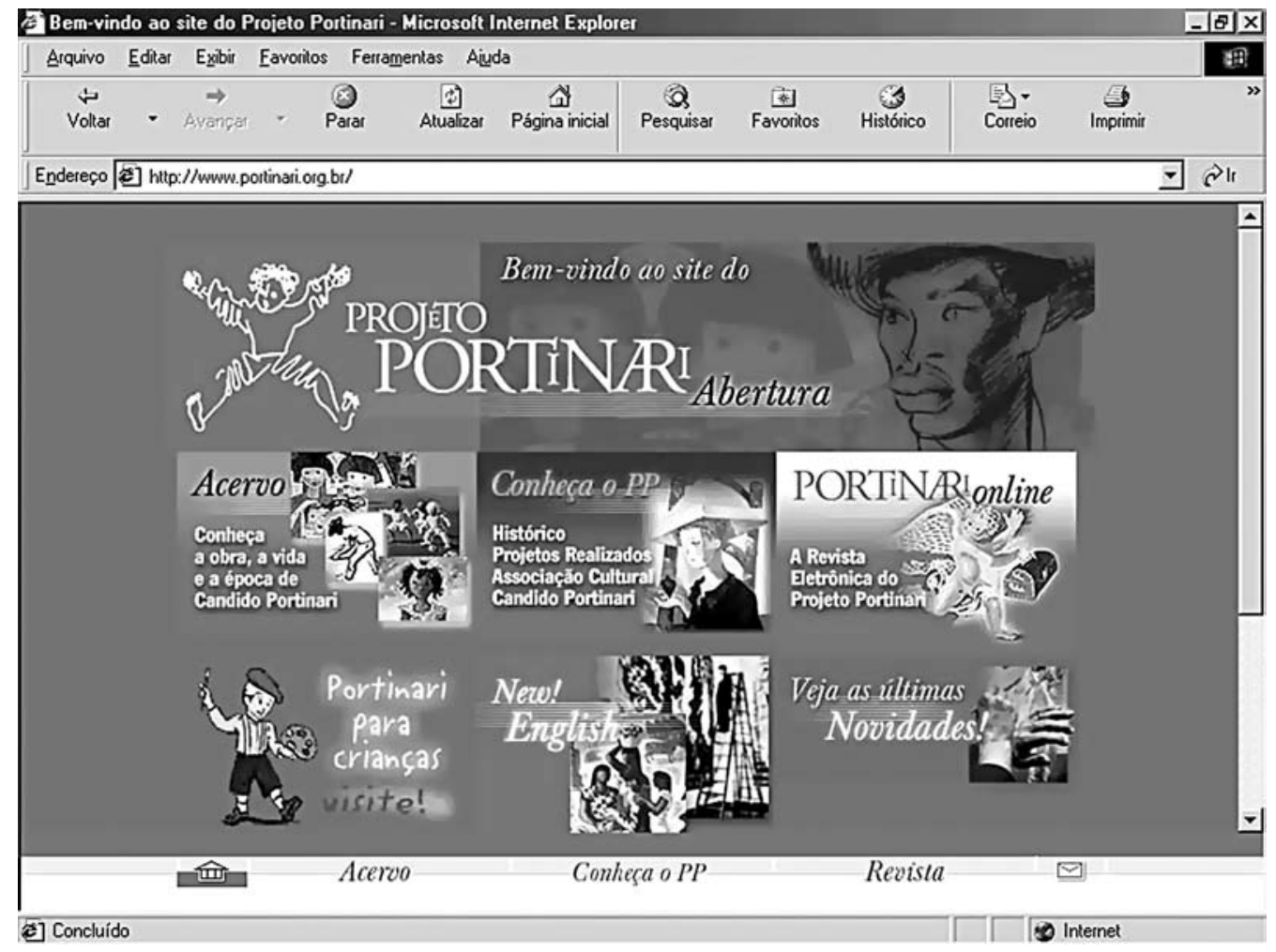


O site do Detective apresenta uma proposta que aponta caminhos atuais e inovadores, propõe ensinar a história da arte com personagens, enredos e conflitos. O Museu Portinari é também um bom exemplo porque parte de um personagem, o Candinho, que relata as experiências e processos de criação do artista Cândido Portinari ${ }^{23}$.

\section{CONSIDERAÇÕES EM TRÂNSITO}

Neste artigo, concentramo-nos na cadeia, agora em movimento, da exposição/divulgação da arte, da recepção, do produto artístico e da criação da arte. Para nós, o jogo é estrutura e proposta em potencial para que cada elemento dessa cadeia se movimente e adquira a função do outro. O jogo traz como essência a interatividade e a abertura para a experiência, o contato e a partilha. Por isso, afirmamos a internet como mais um espaço vivo, de exposição e informação da arte, portanto, propício para ensinar a arte contemporânea, por meio das poéticas da experimentação e da conexão. Sugerimos potencializar a internet, os museus virtuais e os jogos de arte didáticos mediante os processos de criação e de comunicação coletivos.

Por final, verificamos que o jogo em si não é suficiente para construir o conhecimento da arte; e a experiência da crítica da arte; é preciso ainda da mediação de um arte-educador, de um diálogo sobre o que os jovens apreenderam desse jogo e de atividades específicas que permitam a recriação, a transformação dessas imagens e das percepções - decorrentes do jogo - em outras experiências artísticas e estéticas.

Resumo: Este artigo aborda algumas questões surgidas durante uma ação educativa ${ }^{24}$ que integrou o ensino da arte visual na internet com os jogos na web. Destacamos algumas delas: em que contexto os atuais jogos on-line se situam? É a internet um espaço apropriado para ensinar todos os estilos e períodos da história da arte visual? Quais as possibilidades desses jogos para ensinar a história das artes visuais? Para nos aproximar destas questões, analisamos algumas propostas em forma de jogos presentes nos sites de museus e galerias, das associações de arte e de educação. Construímos nossa análise fundamentados em alguns autores das áreas da comunicação, da sociologia, da história e do ensino da arte, nos depoimentos e nas obras de artistas da internet e no deslocamento dinâmico que ocorre entre o produto artístico, a mídia, o receptor e o artista.

Palavras-chave: ensino da arte, internet, jogos, fluxo informacional, gestos críticos, poética da experimentação.
Abstract: This article highlights some issues that appeared along an educative action that integrated Visual Art History teaching in the Internet with Web games. Some of them are: in which context are current online games situated? Is the Internet an appropriate space to teach all styles and periods of Visual Art History? Is it possible to teach Visual Art History using these games? To approach these issues, this article analyzes some proposals in the form of games presented in museums, galleries, and art and education associations websites. It builds its analysis based not only on some authors in the areas of Communication, Sociology, History and Art teaching, but also on testimonies, on works of Internet artists and on the dynamic displacement that occurs among artistic product, media, receptor and artist.

Keywords: art teaching, Internet, games, information flow, critical gestures, poetics of experimentation.
23. PORTELLA, Adriana. Aprendizagem da arte e o Museu Virtual do Projeto Portinari. In: BARBOSA, Ana Mae (Org.). Inquietações e mudanças no ensino da arte. São Paulo: Cortez, 2002. p. 123-137.

24. O tema do presente texto surgiu durante 0 desenvolvimento do projeto CAAP (Communications Alliens Around the Planet), no ano de 2001. $O$ projeto $C A A P$, desde 1998, explora a educação informal a distância por meio da internet com grupos de jovens e professores de escolas públicas e privadas, do Brasil e do exterior. $\mathrm{O}$ projeto tem a supervisão do prof. dr. Ismar de Oliveira Soares, do Núcleo de Comunicação e Educação, NCE/ ECA/USP, e contou com a coordenação da profa. dra. Tania Callegaro. 